\title{
Asupan Gizi Makro dan Durasi Tidur pada Remaja Usia 16-18 Tahun dan Hubungannya terhadap Lama Menstruasi
}

\section{Macro Nutrient Intake and Sleep Duration of Adolescents Aged 16-18 Years Old and Their Relationship with Menstrual Duration}

\author{
Lilia Faridatul Fauziah, Diffah Hanim, Eti Poncorini Pamungkasari \\ Program Pascasarjana Ilmu Gizi Universitas Sebelas Maret Surakarta \\ (3003lili@gmail.com)
}

\begin{abstract}
ABSTRAK
Faktor-faktor yang mempengaruhi variasi lama menstruasi akan merubah ritme hormonal siklus hipotalamus-pituitari-ovarium, sehingga secara tidak langsung merubah kadar sekresi hormon reproduksi. Asupan gizi diperkirakan menjadi salah satu faktor dalam pengaturan hormon reproduksi ini, demikian juga siklus tidur dan bangun pada remaja. Penelitian ini menganalisis hubungan asupan gizi makro dan durasi tidur dengan lama menstruasi pada remaja usia 16-18 tahun. 120 remaja putri dari 6 SMA Kota Magelang-Jawa Tengah berpartisipasi dalam studi cross sectional ini, dipilih menggunakan tehnik cluster random sampling. Data variabel bebas dan terikat dikumpulkan melalui tehnik wawancara menggunakan kuesioner. Analisis dengan uji korelasi untuk menganalisis hubungan antar masing-masing variabel bebas dengan variabel terikat ( $p$-value $<0,05)$ dan regresi linear berganda untuk mengetahui besarnya hubungan seluruh variabel bebas terhadap variabel terikat. Hasil uji korelasi Pearson, terdapat hubungan signifikan antara asupan energi $(\mathrm{r}=0.397: \mathrm{p}=0.000)$, lemak $(\mathrm{r}=0.396: \mathrm{p}=0.000)$, karbohidrat $(\mathrm{r}=0.337: \mathrm{p}=0.000)$, dan durasi tidur $(\mathrm{r}=0.315: \mathrm{p}=0.000)$ dengan lama menstruasi, sedangkan hasil uji korelasi Spearman Rank pada asupan protein tidak signifikan $(r=0.018: p=0.841)$. Nilai $R 2=0.252$. Penting untuk mengatur asupan gizi makro dan durasi tidur agar remaja memiliki lama menstruasi yang normal.
\end{abstract}

Kata kunci : Gizi makro, durasi tidur, menstruasi

\section{ABSTRACT}

Factors influence variations in adolescent menstrual duration would change the hormonal rhythm of the hypothalamic-pituitary-ovarian cycle, so that it indirectly changes the level of secretion of the reproductive hormones. Nutritional intake is predicted to be one of the factors in the regulation of reproductive hormones, as well as the sleep and wake cycles in a teenager. This study analyzed the relationship between macro nutrient intake and sleep duration with menstrual duration in adolescents aged 16-18 years. 120 adolescents was selected by using cluster random sampling from 6 high schools in Magelang City-Central Java for this cross sectional study. All of variable were collected through interview techniques using a questionnaire. Analysis with correlation test and multiple linear regression used to analyze the relationship between each independent variable with the dependent variable with a significance value $<0.05$ and the relationship of all independent variables on the dependent variable. The correlation (Pearson correlation test) between energy intake $(r=0.397: p=0.000)$, fat $(r=0.396: p=0.000)$, carbohydrate $(r=0.337: p=0.000)$, and sleep duration $(r=0.315: p=0.000)$ with menstrual duration was significant, whereas for protein intake (Spearman Rank test) was not significantly associated $(r=0.018: p=0.841)$. The value of $R 2=0.252$.Based on this, it is important to regulate macro nutrient intake and sleep duration for having normal menstrual duration.

Keywords : Macro nutrient, sleep duration, menstruation 


\section{PENDAHULUAN}

Penelitian yang berhubungan dengan menstruasi telah banyak dilakukan, beberapa diantaranya membahas tentang faktor-faktor yang mempengaruhi siklus menstruasi dan Pre-Menstrual Syndrome (PMS), ${ }^{1,2}$ tetapi belum banyak penelitian yang membahas tentang lama menstruasi atau panjangnya fase pengeluaran darah menstruasi. Pada fase menstruasi atau fase pengeluaran darah seringkali terjadi ketidaknyamanan yang dialami oleh seorang wanita, termasuk remaja putri, seperti rasa sakit atau kram pada perut, pusing, merasa mudah tersinggung, dan sensitive, ${ }^{3}$ sehingga remaja putri cenderung menghindari aktivitas ringan maupun berat selama perdarahan atau fase menstrusi. Terdapat $67.8 \%$ remaja putri melakukan pembatasan aktivitas selama fase menstruasi atau fase pengeluaan darah, seperti tidak melakukan olahraga, memasak, bermain dengan teman sebaya, berkebun, menimba air, menyediakan makanan bagi tamu, berada di sekitar teman lakilaki dikarenakan kecemasan mereka akan bau badan mereka saat menstrusi, bahkan ada beberapa dari mereka yang memilih tidak masuk sekolah, dan tidak mengerjakan tugas sekolah. ${ }^{4}$ Pembatasan aktivitas dan respon fisiologis akibat dari datangnya menstruasi tersebut akan mengurangi produktivitas remaja, sehingga diperkirakan semakin panjang lama menstruasi maka semakin banyak pula waktu tidak produktif bagi remaja. Selain itu, lama menstruasi atau panjangnya hari dalam fase pengeluaran darah juga dapat menentukan kesuburan seorang wanita. ${ }^{5}$

Lama menstruasi pada remaja cenderung bervariasi, sebesar 3.2\% dari kelompok penelitian pada remaja putri di Italia memiliki lama menstruasi $<4$ hari dan $19 \%>6$ hari. ${ }^{6}$ Survei yang dilakukan oleh Departmen Pediatrik sebuah Rumah Sakit Anak di Ohio Amerika Serikat kepada 105 remaja putri, 63 diantaranya mengalami menstruasi lebih dari 7 hari atau sebesar $60 \%{ }^{7}$ Penelitian lain pada kelompok remaja putri di Pokhara mengalami lama menstruasi 3-7 hari, yaitu sebesar $88.8 \% .{ }^{8}$ Terdapat banyak faktor yang mempengaruhi variasi dalam lama menstruasi remaja. Faktor-faktor tersebut merubah ritme hormonal siklus hipotalamuspituitari-ovarium, sehingga secara tidak langsung juga merubah kadar sekresi hormon yang dihasilkan oleh hipotalamus-pituitari-ovarium, seperti
LH (Luteinizing Hormonei) dan FSH (Follicle Stimulating Hormone). ${ }^{9}$ Menstruasi terjadi sebagai akibat adanya interaksi antara hipotalamus, hipofisis (yang terdapat di otak), ovarium, dan uterus (rahim).$^{10}$ Sebuah penelitian menyebutkan bahwa peningkatan hormon FSH dan progesteron berhubungan secara signifikan dengan peningkatan lama atau durasi menstruasi. ${ }^{11}$ Asupan gizi dapat mempengaruhi fungsi kerja hipotalamus hipofisis dan periode menstruasi. Makan makanan tinggi karbohidrat dan lemak yang berlebih akan meningkatkan kadar insulin dalam tubuh, seperti pada kasus remaja putri yang mengalami Binge Eating. Di Indonesia, 40,6\% penduduk mengonsumsi makanan dibawah kebutuhan minimal (kurang dari 70\% dari Angka Kecukupan Gizi/AKG) yang dianjurkan dan pada kelompok usia remaja sebesar $40.2 \% .^{12}$ Secara umum konsumsi energi maupun protein di Kota Magelang masih di bawah standar kecukupan yang disyaratkan Widya Karya Nasional Pangan dan Gizi, yaitu 1.820 kkal dan 54.01 gram. Pola konsumsi di Kota Magelang juga didominasi oleh konsumsi makanan dan minuman jadi, salah satu dari makanan jadi tersebut adalah makanan fast food dan camilan yang sedikit mengandung gizi. ${ }^{13}$

Masa remaja ditandai dengan perubahan biologis dan sosial yang dapat mempengaruhi keadaan kesehatan dan perilaku, salah satunya adalah perubahan pola tidur. ${ }^{14}$ Durasi tidur merupakan salah satu komponen dari pola tidur. Sebuah penelitian menyebutkan bahwa kehilangan waktu tidur atau kurang tidur akan berpengaruh terhadap sekresi hormon reproduksi. ${ }^{15}$ Kurangnya durasi tidur seringkali terjadi pada remaja dan dapat mempengaruhi kesejahteraan hidup, seperti pada penelitian remaja putri SMA di China, kurang tidur pada remaja putri berhubungan secara signifikan dengan kejadian menstruasi yang lebih dari 7 hari. ${ }^{16}$ The Centers for Disease Control and Prevention merekomendasikan durasi tidur untuk remaja adalah 9-10 jam per hari, tetapi berdasarkan penelitian yang dilakukan pada anak-anak SMA di Amerika, 95\% remaja tidak memenuhi rekomendasi tersebut. ${ }^{17}$ Beberapa penelitian menunjukkan bahwa $24-73 \%$ remaja tidur kurang dari 7 jam per hari pada hari-hari aktif sekolah, ${ }^{18,19}$ hal ini lebih sedikit dibandingkan dari kebutuhan yang seharusnya, yaitu 9 jam..$^{20}$ 
Berdasarkan penjelasan tersebut dapat diketahui bahwa terdapat variasi dalam lama menstruasi pada remaja. Lama menstruasi menjadi salah satu penilaian terhadap karakteristik menstruasi melalui hormon reproduksi. Asupan gizi diperkirakan menjadi salah satu faktor dalam pengaturan hormon reproduksi ini dan demikian juga dengan siklus tidur dan bangun pada seorang remaja, sehingga peneliti merasa perlu melakukan kajian lebih lanjut untuk mengetahui karakteristik asupan gizi makro dan durasi tidur pada remaja usia 16-18 tahun, serta menganalisis hubungannya dengan lama menstruasi.

\section{BAHAN DAN METODE}

Penelitian dilaksanakan pada bulan Agustus sampai September tahun 2018 di Kota Magelang, Propinsi Jawa Tengah dengan populasi remaja putri usia 16-18 tahun yang duduk di kelas 10 dan 11 SMA Kota Magelang yang berasal dari 32 SMA dan sederajat. Perhitungan jumlah sampel menggunakan rumus perhitungan solvin yaitu $\mathrm{n}=\mathrm{N} / 1+(\mathrm{d})^{2}$ dengan menggunakan $\mathrm{d}=0.1$ dan $\mathrm{N}=7.536$, maka perkiraan jumlah sampel minimal yang dibutuhkan adalah 99.9 dan dibulatkan menjadi 100 . Untuk mengantisipasi adanya sampel yang mengundurkan diri atau drop out saat penngumpulan data maka dilakukan penambahan $20 \%$, sehingga dari populasi sebesar 7.536 siswi didapatkan besar sampel sebanyak 120 siswi. Cara pengambilan sampel yang digunakan adalah menggunakan tehknik Cluster Random Sampling, dikarenakan populasi terdiri dari kelompok-kelompok individu atau cluster yang tersebar sangat luas. Proses pengambilan sampel secara acak pada kelompok individu dalam suatu gugusan atau kelompok sekolah. Sekolah SMA dan sederajat di Kota Magelang berjumlah 32 sekolah dan dipilih 6 sekolah secara acak. Setelah memilih sampel sekolah, dilanjutkan membagi pengambilan 120 siswi secara merata, sehingga masing-masing sekolah berjumlah 20 siswi.

Pemilihan siswi sebagai responden dipilih secara acak berdasarkan kriteria inklusi. Kriteria inklusi responden diantaranya adalah berusia antara 16-18 tahun yang sedang duduk di kelas 10 dan 11 , memiliki IMT normal $\left(18.5-<25 \mathrm{~kg} / \mathrm{m}^{2}\right)$, mengalami menstruasi pertama kali atau menarche pada usia 12-15 tahun, dan mengisi inform con- cent. Pemilihan usia remaja 16-18 tahun dikarenakan pada usia ini sering terjadi variasi lama menstruasi, selain itu usia yang semakin bertambah, pendidikan yang rendah, dan obesitas dapat menjadi faktor lain yang dapat mempengaruhi lama dan jumlah menstruasi, ${ }^{21}$ sehingga homogenitas usia dan IMT pada penelitian ini dimaksudkan untuk meminimalkan kerancuan yang berasal dari faktor usia dan IMT. Hipotalamus memiliki peran penting dalam mengatur fungsi reproduksi, salah satunya adalah yang berhubungan dengan menstruasi, tetapi hipotalamus sendiri tetap dipengaruhi oleh rangsangan dari otak, misalnya adanya stress dan kecemasan, ${ }^{22}$ sehingga pemilihan kelas 10 dan 11 dimaksudkan untuk membuat responden pada kelompok yang sama dalam hal tingkat stress karena kelas 10 dan 11 cenderung memiliki aktivitas dan beban belajar yang sama baik selama di sekolah maupun di luar sekolah. Pemilihan responden dengan kriteria inklusi menarche usia 1215 tahun untuk menghindari responden yang kemungkinan mengalami gangguan menstruasi. Usia menarche yang terlalu dini maupun lambat dapat dikaitkan dengan terjadinya gangguan menstruasi pada seorang wanita, tetapi lebih banyak terjadi pada wanita yang mengalami menarche pada usia yang terlalu dini. ${ }^{23}$

Desain penelitian ini adalah cross sectional dengan pengumpulan data melalui tehnik wawancara menggunakan kuesioner Recall 24 jam sebanyak 3 kali pertemuan secara acak untuk variabel asupan gizi makro yang meliputi asupan energi, protein, lemak, dan karbohidrat. Pertemuan sebanyak 3 kali secara acak bertujuan untuk mendapatkan gambaran kebiasaan asupan gizi secara lebih representatif dan optimal dengan adanya variasi yang lebih besar dalam asupan gizi dari makanan harian individu. Prinsip dari metode recall 24 jam adalah dengan mencatat jenis dan jumlah bahan makanan yang dikonsumsi pada periode 24 jam yang lalu. Dalam metode ini, responden menceritakan semua yang dimakan dan diminum selama 24 jam yang lalu (kemarin). Dimulai sejak responden bangun pagi hingga akan tidur pada malam hari. Hasil dari pencatatan tersebut akan menghasilkan jumlah rata-rata gizi makro (energi, protein, lemak, dan karbohidrat) yang berasal dari makanan yang dikonsumsi per hari dalam satuan gram, data yang dihasilkan berbentuk rasio. Pengumpulan data un- 
tuk variabel durasi tidur menggunakan kuesioner PSQI (Pittsburgh Sleep Quality Index) sebanyak 1 kali pertemuan. PSQI (Pittsburgh Sleep Quality Index) adalah instrumen yang dikembangkan oleh oleh Busyee, Reynolds, Monk, et al., tahun 1989 untuk mengukur kualitas tidur seseorang. Kuesioner ini telah digunakan oleh beberapa peneliti di berbagai negara. PSQI dianggap memadai untuk digunakan pada remaja dan orang dewasa ${ }^{24}$ dan merupakan instrumen yang valid dan dapat diandalkan untuk menilai kualitas tidur karena sederhana, selain itu juga tetap dapat dipahami dan dijawab oleh penderita dimensia. ${ }^{25}$

Dilakukan uji validitas dan reliabilitas pada PSQI dalam Bahasa Indonesia yang digunakan dalam penelitian sebelumnya, yang mana hasilnya adalah kuesioner PSQI ini merupakan instrumen yang dapat diandalkan dan shahih. ${ }^{26}$ Kuesioner ini mengkaji 7 dimensi dalam kualitas tidur yaitu kualitas tidur subjektif, latensi tidur, durasi tidur, efisiensi kebiasaan tidur, gangguan tidur, penggunaan obat tidur, dan disfungsi aktivitas pada siang hari. Pada penelitian ini definisi operasional dari durasi tidur adalah total jumlah waktu tidur dalam sehari dengan satuan jam. Pengumpulan data untuk variabel lama menstruasi menggunakan kuesioner yang berbentuk tabel seperti flowchart yang berisi tanggal dan bulan untuk menulis data menstruasi 3 bulan terakhir dari responden. Responden akan memberikan tanda pada tabel sesuai tanggal dan bulan datangnya menstruasi, dengan tanda $\mathrm{S}$ yang berarti Spotting dan B yang berarti Bleeding.

Analisis bivariat dilakukan terhadap dua variabel yang diduga berhubungan atau berkorelasi. Dalam penelitian ini analisis bivariat menggunakan uji analisis Pearson untuk data yang berdistribusi normal, dan Spearman Rank untuk data yang berdistribusi tidak normal. Uji analisis dilakukan dengan bantuan SPSS 17 menggunakan derajat kesalahan $\alpha(0,05)$, untuk mengetahui hubungan antara variabel bebas dengan variabel terikat, yaitu hubungan antara asupan gizi makro yang terdiri dari asupan energi dengan lama menstruasi, asupan protein dengan lama menstruasi, asupan lemak dengan lama menstruasi, asupan karbohidrat dengan lama menstruasi, dan hubungan antara durasi tidur dengan lama menstruasi. Selanjutnya dilakukan analisis multivariat dengan menggunakan analisis regresi linear berganda un- tuk menghubungkan secara bersama-sama antara seluruh variabel bebas dan variabel terikat pada penelitian ini, dan mengetahui variabel bebas yang memberikan nilai Sumbangan Efektif (SE) terbesar terhadap variabel terikat.

\section{HASIL}

Berdasarkan Tabel 1 diketahui sebagian besar responden adalah berusia 16 tahun, yaitu sebanyak 69 orang $(57.5 \%)$ dan sebagian besar berada di kelas 10 , yaitu sebanyak 68 orang $(56.7 \%)$. Sebagian besar responden pada penelitian ini memiliki IMT antara 18.5-19.4, yaitu sebesar 44 orang atau $36.7 \%$.

Tabel 2 menunjukkan bahwa nilai terendah dari variabel gizi makro untuk asupan energi adalah 493.00 dan tertinggi adalah 2260.73, dengan rerata $1164.64 \pm 367.49$. Nilai terendah dari asupan protein adalah 16.37 dan tertinggi adalah 436.23 dengan rerata $50.69 \pm 41.31$. Nilai terendah asupan lemak adalah 17.23 dan tertinggi adalah 80.60, sedangkan rerata variabel ini adalah $46.12 \pm 15.11$. Nilai terendah asupan karbohidrat adalah 46.37 dan tertinggi 261.73 dengan rerata $144.49 \pm 46.22$. Nilai paling rendah pada variabel durasi tidur adalah 3.00 dan paling tinggi adalah 9.00 dengan rerata $6.47 \pm 1.47$. Nilai rerata untuk variabel lama menstruasi adalah $6.68 \pm 1.47$. Dari keseluruhan variabel pada penelitian ini memiliki nilai SD lebih kecil dibandingkan dengan nilai rerata, sehingga dapat disimpulkan bahwa sebaran 120 responden terhadap masing-masing variabel pada peneli-

\section{Tabel 1. Karakteristik Subjek Penelitian}

\begin{tabular}{lcc}
\hline \multicolumn{1}{c}{ Karakteristik } & $\mathbf{n}$ & $\mathbf{\%}$ \\
\hline Usia (tahun) & & \\
16 & 69 & 57.5 \\
17 & 49 & 40.8 \\
18 & 2 & 1.7 \\
Kelas & & \\
10 & 68 & 56.7 \\
11 & 52 & 43.3 \\
Indeks Massa Tubuh (IMT) & & \\
$18.5-19.4$ & 44 & 36.7 \\
$19.5-20.4$ & 32 & 26.7 \\
$20.5-21.4$ & 14 & 11.7 \\
$21.5-22.4$ & 12 & 10.0 \\
$22.5-23.4$ & 6 & 5.0 \\
$23.5-24.4$ & 6 & 5.0 \\
$24.5-24.9$ & 6 & 5.0 \\
\hline
\end{tabular}


Tabel 2. Hasil Analisis Univariat Pola Makan, Durasi Tidur dan Lama Menstruasi

\begin{tabular}{lccccc}
\hline \multicolumn{1}{c}{ Variabel } & n & Min & Max & Mean & SD \\
\hline Asupan Gizi Makro & & & & & \\
$\quad$ Energi & 120 & 493.00 & 2260.73 & 1164.64 & 367.49 \\
Protein & 120 & 16.37 & 436.23 & 50.69 & 41.31 \\
Lemak & 120 & 17.23 & 80.60 & 46.12 & 15.11 \\
$\quad$ Karbohidrat & 120 & 46.37 & 261.73 & 144.49 & 46.22 \\
Durasi Tidur & 120 & 3.00 & 9.00 & 6.47 & 1.47 \\
Lama Menstruasi & 120 & 3 & 12 & 6.68 & 1.47 \\
\hline
\end{tabular}

Tabel 3. Hasil Analisis Bivariat

\begin{tabular}{ccccc}
\hline \multirow{2}{*}{ Variabel } & \multicolumn{3}{c}{ Lama Menstruasi } & \multirow{2}{*}{ Keterangan } \\
\cline { 2 - 4 } & $\mathbf{r}^{*}$ & $\mathbf{p}^{*}$ & $\mathbf{n}$ & \\
\hline Asupan Energi & 0.397 & 0.000 & 120 & Signifikan \\
Asupan Protein & 0.018 & 0.841 & 120 & Tidak Signifikan \\
Asupan Lemak & 0.369 & 0.000 & 120 & Signifikan \\
Asupan Karbohidrat & 0.337 & 0.000 & 120 & Signifikan \\
Durasi Tidur & 0.315 & 0.000 & 120 & Signifikan \\
\hline
\end{tabular}

*Uji Korelasi Pearson dan Spearman Rank

tian ini terindikasi baik. Nilai paling rendah pada variabel durasi tidur adalah 3.00 dan paling tinggi adalah 9.00 , dengan rerata $6.47 \pm 1.47$, dan sebaran 120 responden pada variable ini juga baik dikarenakan nilai SD lebih kecil jika dibandingkan dengan nilai rerata. Tabel 2 juga menunjukkan nilai paling rendah dari variabel lama menstruasi adalah 3 dan paling tinggi untuk variabel menstruasi adalah 12 dengan rerata sebesar $6.68 \pm 1.47$.

Tabel 3 menunjukkan hasil setelah dilakukan analisis dengan menggunakan uji korelasi Pearson pada variabel asupan energi dengan lama menstruasi, yaitu dari $\mathrm{n}=120$ diperoleh nilai besar korelasi $r=0.397$ dan angka sig.(2-tailed) adalah 0.000 , nilai ini lebih kecil daripada batas kritis $\alpha=0.05$ yang berarti terdapat hubungan positif antara asupan energi dengan lama menstruasi $(p<0.05)$, meskipun hubungan kedua variabel ini rendah. Hasil uji korelasi Pearson pada variabel asupan lemak adalah $r=0.369$ dan angka sig. (2-tailed) adalah 0.000 yang berarti terdapat hubungan positif yang rendah antara asupan lemak dengan lama menstruasi $(p<0.05)$, sedangkan hasil uji korelasi Perason pada variabel asupan karbohidrat dengan lama menstruasi adalah $r=0.337$ dengan angka sig.(2-tailed) sebesar 0.000 yang berarti terdapat hubungan positif yang rendah antara asupan karbohidrat dengan lama menstruasi $(p<0.05)$. Hasil uji korelasi Spearman Rank pada variabel asupan protein adalah $r=0.018$ dan angka sig.(2-tailed) adalah 0.841 yang berarti tidak terdapat hubungan antara asupan protein dengan lama menstruasi $(p>0.05)$.

Analisis uji korelasi Pearson pada variabel durasi tidur dan lama menstruasi adalah dari $\mathrm{n}=120$ diperoleh nilai besar korelasi $r=0.315$ dan angka sig.(2-tailed) adalah 0.000 dimana nilai ini lebih kecil daripada batas kritis $\alpha=0.05$ yang berarti terdapat hubungan positif yang rendah antara durasi tidur dengan lama menstruasi $(p<0.05)$.

Model persamaan regresi linear berganda pada peneltian ini adalah $\mathrm{Y}=3.587+0.001 \mathrm{X}_{1}$ $-0.007 \mathrm{X}_{2}+0.019 \mathrm{X}_{3}+0.005 \mathrm{X}_{4}+0.142 \mathrm{X}_{5}+\mathrm{e}$. Hasil analisi regresi linear berganda menunjukkan nilai $\mathrm{F}_{\text {hitung }} 7.677$ dengan tingkat signifikansi 0.000 , sedangkan $\mathrm{F}_{\text {tabel }}$ pada tingkat kepercayaan $95 \%(\alpha$ $=0.05)$ adalah 2.46, dengan demikian $\mathrm{F}_{\text {hitung }}>\mathrm{F}_{\text {ta- }}$ ${ }_{b e l}(7.667>2.46)$ dan tingkat signifikannya adalah $p<0.05$. Berdasarkan hasil analisis tersebut dapat disimpulkan bahwa variabel asupan gizi makro, yaitu energi, protein, lemak, karbohidrat, dan durasi tidur secara simultan atau bersama-sama berpengaruh terhadap lama menstruasi. Asupan energi memberikan Sumbangan Efektif (SE) yang paling besar terhadap lama menstruasi, yaitu sebesar 7.5\%. Berdasarkan hasil analisis ini juga diperoleh nilai $\mathrm{R}=0.502$ yang berarti hubungan antara asupan energi sebagai $\mathrm{X}_{1}$, asupan protein sebagai 
Tabel 4. Hasil Analisis Multivariat

\begin{tabular}{ccccccc}
\hline Variabel & $\begin{array}{c}\text { Koefisien } \\
\text { Korelasi (r) }\end{array}$ & $\begin{array}{c}\text { Koefisien } \\
\text { Regresi (Beta) }\end{array}$ & $\mathbf{p}$ & $\boldsymbol{R}$ Square* & SE & SR \\
\hline Asupan Energi & 0.397 & 0.187 & 0.254 & & 7.5 & 29.8 \\
Asupan Protein & 0.018 & -0.187 & 0.045 & -0.3 & -1.6 \\
Asupan Lemak & 0.369 & 0.193 & 0.080 & 0.252 & 7.1 & 28.6 \\
Asupan Karbohidrat & 0.337 & 0.170 & 0.195 & & 5.8 & 23.1 \\
Durasi Tidur & 0.315 & 0.143 & 0.113 & & & \\
\hline F $_{\text {hitung }}$ & & & 7.677 & & \\
Sig F & & $0.000^{\mathrm{a}}$ & & & \\
R & & $0.502^{\mathrm{a}}$ & & & \\
\hline
\end{tabular}

*Uji Regresi Linear Berganda

$\mathrm{X}_{2}$, asupan lemak sebagai $\mathrm{X}_{3}$, asupan karbohidrat sebagai $\mathrm{X}_{4}$, dan durasi tidur sebagai $\mathrm{X}_{5}$, terhadap lama menstruasi (Y) sebesar 50.2\%. Berdasarkan tingkat hubungan atau intepretasi koefisien korelasi nilai $\mathrm{r}$, nilai $50.2 \%$ berarti termasuk dalam kategori hubungan cukup kuat. Selanjutnya berdasarkan perhitungan nilai koefisien determinasi $R$ Square, yang mana diperoleh nilai sebesar 0.252 , artinya adalah $25.2 \%$ faktor yang mempengaruhi lama menstruasi dapat dijelaskan oleh asupan gizi makro yaitu asupan energi, protein, lemak, karbohidrat, dan durasi tidur. Sedangkan sisanya sebesar $74.8 \%$ dapat dijelaskan oleh faktor selain yang diteliti dalam model regresi ini.

\section{PEMBAHASAN}

Hasil penelitian menunjukkan bahwa sebagian besar responden memiliki lama menstruasi 4-7 hari, yaitu sebanyak 91 orang atau sebesar $75.83 \%$, sedangkan sisanya sebesar 27 orang atau $22.5 \%$ mengalami menstruasi selama $>7$ hari. Karakteristik menstruasi normal pada remaja adalah menarche pada usia rata-rata 12.43 tahun, siklus menstruasi 21-45 hari, lama menstruasi $\leq 7$ hari. ${ }^{27}$ Hasil yang sama juga ditemukan pada remaja putri di India, sebagian besar remaja putri memiliki lama menstruasi antara 2-7 hari ${ }^{28}$ dan pada remaja putri di Ethiopia. ${ }^{29}$ Hari pertama menstruasi menandai siklus menstruasi berikutnya. Pada masa fase menstruasi ini sekelompok folikel yang baru telah direkrut dan akan berlanjut menjadi folikel yang matang. Salah satu dari folikel yang matang tersebut akan berovulasi. Fenomena menstruasi merupakan peristiwa endometrial yang dipicu oleh hilangnya dukungan progesteron terhadap korpus luteum pada saat siklus non-konsepsi. ${ }^{30}$
Hasil pada penelitian ini menunjukkan bahwa rerata asupan energi pada responden adalah 1164.64yang berarti rata-rata asupan energi responden sebesar $54.81 \%$ dari AKG (Angka Kecukupan Gizi), rerata asupan lemak 46.12 yaitu rata-rata asupan lemak responden adalah sebesar 64.96\% dari AKG, dan rerata asupan karbohidrat 144.49 yaitu rata-rata asupan karbohidrat responden hanya sebesar $49.48 \%$ dari AKG. Sedangkan rerata asupan protein adalah 50.69 atau rata-rata asupan protein responden adalah sebesar $85.94 \%$. Berdasarkan hal tersebut dapat disimpulkan bahwa rata-rata responden pada penelitian ini termasuk dalam kategori defisit berat pada asupan energi, lemak, dan karbohidrat, sedangkan untuk asupan protein, rata-rata responden termasuk pada kategori defisi ringan. Hal tersebut didasarkan pada hasil perhitungan rata-rata asupan energi, protein, lemak, dan karbohidrat per hari melalui Recall 24 jam yang dilakukan sebanyak 3 pertemuan pada hari yang diacak, yang kemudian dibandingkan dengan Angka Kebutuhan Gizi (AKG) remaja usia 16-18 tahun. AKG bagi golongan remaja putri usia 16-18 tahun untuk energi adalah sebesar $2125 \mathrm{kkal} / \mathrm{hari}$, protein sebesar $59 \mathrm{gr} / \mathrm{hari}$, lemak sebesar 71 gr/hari, dan karbohidrat sebesar 292 gr/hari, jika asupan energi, protein, lemak, dan karbohidrat $<70 \%$ AKG maka digolongkan pada kategori defisit berat, 70-79\% AKG termasuk kategori defisit sedang, 80-89\% AKG kategori defisit ringan, 90-119\% kategori baik, dan jika $\geq 120 \%$ AKG termasuk kategori lebih. ${ }^{31}$ Hasil yang serupa juga ditemukan pada penelitian yang dilakukan di Negara Asia lain, yaitu di India, sekitar 75\% responden yang terdiri dari remaja putri usia 11-16 tahun memiliki asupan gizi makro yang rendah 
dibandingkan dengan AKG yang dianjurkan. ${ }^{32}$

Salah satu kebiasaan makan remaja adalah makan makanan ringan atau "ngemil'(snacking), secara umum makanan selingan diartikan sebagai suatu menu spesifik yang memiliki porsi yang lebih kecil dengan nilai gizi yang rendah dan murah. ${ }^{33}$ Setelah mengonsumsi makanan selingan, seseorang akan cenderung mengonsumsi lebih banyak kalori, dibandingkan setelah mengonsumsi makanan utama. Contoh makanan selingan/ snack berdasarkan sebuah penelitian yang mengategorikan 2 jenis makanan (makanan utama dan camilan) adalah sereal, biskuit, keripik, kacang panggang, yoghurt, buah kering, permen, cookies, puding, dan marshmallow. ${ }^{34}$ Sebuah penelitian menyebutkan bahwa sebagian besar remaja selalu menghabiskan waktu dengan menonton televisi sambil mengonsumsi makanan ringan (cemilan), yang mana makanan selingan tersebut secara signifikan $(p<0.01)$ berhubungan dengan makanan yang memiliki pemanis buatan dan memiliki sedikit kandungan gizi ${ }^{35}$.

Hasil wawancara pada responden dalam penelitian ini, remaja seringkali membeli makananmakanan ringan di luar (kantin sekolah dan penjual makanan keliling) dan melewatkan makan utama (sarapan, makan siang, dan malam), hal ini yang diperkirakan menyebabkan rata-rata responden memiliki asupan gizi makro dengan kategori defisit berat. Responden dalam penelitian ini juga menyebutkan bahwa pembatasan makan yang dilakukan, dikarenakan kekhawatiran akan berat badan yang berlebih, meskipun pada akhirnya pembatasan yang dilakukan justru menyebabkan AKG tidak terpenuhi dikarenakan kesalahan dalam pemilihan menu makanan atau diet yang tidak tepat.

Hasil analisis bivariat untuk variabel asupan gizi dengan lama menstruasi yang memiliki hubungan signifikan adalah asupan energi, asupan lemak, dan asupan karbohidrat dengan p-value $<$ 0.05 (0.000), sedangkan asupan protein tidak berhubungan signifikan dengan lama menstruasi dengan $p$-value $>0.05(0.841)$. Hasil penelitian menyebutkan bahwa wanita dengan menstruasi normal memiliki persentase energi dari lemak total, total PUFA, dan asam linolenat yang meningkatkan konsentrasi kadar testosteron dan progesteron, yang mana progesteron dapat menurunkan resiko tidak subur. ${ }^{36}$ Penebalan dinding rahim saat masa ovulasi sebelum terjadi fase menstruasi juga membutuhkan energi lebih besar untuk pasokan oksigen, ${ }^{14}$ sehingga asupan energi yang cukup akan membuat seorang wanita memiliki menstruasi yang normal.

Lemak memiliki peran dalam mengatur sekresi GnRH yang akan memacu hipofisi untuk melakukan pelepasan FSH (Follicle Stimulating Hormone) dan LH (Lutheinizing Hormone), serta berhubungan dengan menstruasi. ${ }^{37}$ Seseorang yang melakukan pembatasan makan atau diet pada makanan tertentu untuk menurunkan berat badan, secara signifikan berhubungan dengan gangguan lama menstruasi $\left(<2\right.$ hari dan $>7$ hari).$^{38}$ Pada penelitian lain yang sejenis, terdapat peningkatan kejadian oligomenore, polimenore, dan hipermenore pada responden yang melakukan puasa lebih dari 15 hari di bulan Ramadhan. ${ }^{39}$ Pada saat melakukan puasa, secara otomatis maka akan terjadi perubahan pola makan yang mempengaruhi asupan energi, protein, lemak dan karbohidrat. Melewatkan makan pagi (sarapan) dan kebiasaan makana makanan cepat saji yang memiliki kandungan gizi rendah memberikan pengaruh yang signifikan terhadap meningkatnya kejadian oligomenore pada remaja putri, ${ }^{40}$ tetapi pada penelitian lain disebutkan bahwa frekuensi konsumsi makanan manis yang berlemak, tidak berhubungan secara signifikan terhadap kejadian gangguan pre menstruasi dan perdarahan selama menstruasi.$^{41}$ Meskipun secara statistik variabel asupan protein tidak berhubungan dengan lama menstruasi, tetapi asupan protein yang sesuai dengan kebutuhan remaja akan bermanfaat untuk mempertahankan fungsi normal metabolisme tubuh bersama-sama dengan zat gizi lainnya, salah satunya fungsi normal reproduksi. Makanan yang dikonsumsi akan menentukan zat gizi yang masuk ke dalam tubuh, yang mana pada akhirnya akan mempengaruhi status gizi. Status gizi secara signifikan mempengaruhi siklus menstruasi, lama menstruasi, jumlah perdarahan, dan pre-menstrual symptoms (PMS) pada remaja. ${ }^{42}$

Hasil penelitian ini menemukan nilai rerata durasi tidur 6.47. Rekomendasi durasi tidur bagi remaja usia 16-18 tahun adalah antara 8-10 jam atau 7-9 jam. ${ }^{43}$ Pada proses perkembangan remaja awal, remaja mulai memilih tidur lebih lambat pada malam hari dikarenakan kegiatan pada siang 
hari yang berlanjut sampai dengan menjelang malam. Aktivitas yang berulang tersebut pada akhirnya menjadi sebuah ritme sirkadian pada remaja. ${ }^{44}$ Beberapa diantara responden dalam penelitian ini mengatakan bahwa aktivitas diatas tempat tidur yang seringkali dilakukan sebelum tidur adalah bermain gadget atau ponsel, baik itu bermain game ataupun beraktivitas di dunia maya melalui sosial media. Hal tersebut juga disebutkan dalam penelitian lain bahwa penggunaan gadget atau media elektronik baik di siang hari maupun menjelang tidur berhubungan dengan risiko pemanjangan SOL (Sleep Onset Latency) dan kurangnya durasi tidur. ${ }^{45}$ Penundaan jam masuk sekolah akan mempengaruhi durasi tidur remaja. Sebagian besar penelitian memperlihatkan peningkatan yang siginifikan pada durasi tidur remaja, bahkan meskipun hanya dengan penundaan jam masuk yang relatif sedikit, yaitu $0.5-1$ jam saja. ${ }^{46} \mathrm{Ha}-$ sil analisis bivariat untuk menemukan hubungan antara durasi tidur dengan lama menstruasi pada penelitin ini adalah nilai korelasi sebesar 0.315 dengan $p$-value $0.000<0.05$. Remaja putri setiap bulan mengalami menstruasi, yang mana menstruasi merupakan suatu sistem hormon yang saling berhubungan antara hipotalamus hipofise pitutary, sehingga hal-hal yang mengganggu fungsi hipotalamus hipofise pitutary akan mempengaruhi menstruasi tersebut. Hormon pitutary disekresikan pada saat seseorang sedang tidur ${ }^{47}$, sehingga durasi tidur yang tidak cukup atau tidak sesuai dengan rekomendasi akan mempengaruhi menstruasi mereka. Hasil yang sama juga ditemukan pada penelitian oleh Lim, et al., ${ }^{48}$ bahwa durasi tidur secara signifikan berhubungan dengan menstruasi seorang remaja. Mekanisme secara tepat belum dapat dijelaskan, namun tidur dapat mempengaruhi FSH dan GnRH, dimana LH dihasilkan setelah satu jam onset tidur dan berlanjut sampai beberapa jam sebelum terjaga. ${ }^{49}$ Penelitian lain menyebutkan bahwa neuron dalam nukleus suprachiasmatic (jam sirkadin) yang memiliki reseptor untuk mengatur estrogen dan progesteron, menunjukkan bahwa terdapat hubungan fungsional antara jam sirkadian (siklus tidur dan bangun tidur) dengan menstruasi. ${ }^{50}$ Hasil yang berbeda ditemukan pada penelitian lain yang menyebutkan bahwa durasi tidur tidak berhubungan secara signifikan, baik dengan lama menstruasi maupun siklus menstruasi. ${ }^{51} \mathrm{Ha}$ - sil yang berbeda tersebut bisa disebabkan karena penggunaan skala data pengukuran variabel durasi tidur yang berbeda dengan penelitian ini.

Hasil analisis multivariat menunjukkan nilai signifikan sebesar 0.000 ( $p$-value $<0,05)$ yang berarti bahwa variabel asupan gizi makro yang terdiri dari asupan energi, protein, lemak, karbohidrat, dan durasi tidur secara simultan atau bersama-sama mempengaruhi lama menstruasi. Model persamaan regresi linear berganda pada peneltian ini menunjukkan bahwa setiap kenaikan $1 \mathrm{kkal}$ asupan energi maka akan menaikkan lama menstruasi sebesar 0.001 hari, setiap kenaikan 1 gram asupan protein akan menurunkan lama menstruasi sebesar 0.007 hari, setiap kenaikan 1 gram asupan lemak akan menaikkan lama menstruasi sebesar 0.019 hari, setiap kenaikan 1 gram asupan karbohidrat akan menaikkan lama menstruasi sebesar 0.005 hari, dan setiap kenaikan 1 jam durasi tidur maka akan menaikkan lama menstruasi sebesar 0.142 hari. Sebesar $25.2 \%$ faktor-faktor yang mempengaruhi lama menstruasi dapat dijelaskan oleh asupan gizi makro yaitu asupan energi, protein, lemak, karbohdrat, dan durasi tidur. Sedangkan sisanya sebesar $74.8 \%$ dapat dijelaskan oleh faktor selain yang diteliti dalam model regresi ini. Pada penelitian lain menyebutkan bahwa usia yang semakin bertambah, pendidikan yang rendah, dan obesitas dapat menjadi faktor lain yang dapat mempengaruhi lama dan jumlah menstruasi. ${ }^{52}$

Kondisi sosial keluarga dapat mempengaruhi lama menstruasi remaja. Perbedaan yang signifikan lama menstruasi antara remaja putri yang tinggal bersama dengan kedua orang tua dan yang tidak tinggal bersama kedua orang tua adalah sebesar 1.02 hari. ${ }^{53}$ Berdasarkan urutan nilai koefisien dari hasil analisis multivariat yang dilakukan, dapat disimpulkan bahwa faktor yang paling mempengaruhi lama menstruasi diantara variabel bebas dalam peneltian ini adalah asupan energi dengan nilai sumbangan efektif sebesar 7.5\%.

\section{KESIMPULAN DAN SARAN}

Terdapat hubungan yang signifikan antara asupan gizi makro untuk asupan energi, lemak, karbohidrat dan durasi tidur dengan lama menstruasi pada remaja usia 16-18 tahun, sedangkan asupan protein tidak memiliki hubungan yang signifikan. Berdasarkan hal tersebut, penting untuk 
mengatur asupan gizi makro dan durasi tidur agar remaja memiliki lama menstruasi yang normal, karakteristik menstruasi yang normal merupakan salah satu tanda normalnya kondisi organ reproduksi. Dengan adanya hasil penelitian ini diharapkan dapat menjadi rujukan ilmiah bagi ahli gizi dan bidan untuk dapat ikut berpartisipasi meningkatkan kesehatan pada remaja, baik gizi kesehatan maupun reproduksi, melalui kerja sama lintas sektoral bersama dengan pihak sekolah maupun organisasi remaja di lingkungan masyarakat. Rendahnya besaran hubungan variabel asupan gizi makro dan durasi tidur dengan lama menstruasi pada remaja pada penelitian ini, yaitu $25.4 \%$, menjadikan tema penelitian yang berhubunga dengan lama menstruasi ini harus perlu dikembangkan lagi dengan menambah variabel-variabel lainnya, seperti status gizi, tingkat kecemasan, dan status sosial ekonomi keluarga.

\section{DAFTAR PUSTAKA}

1. DiMatteo, J., Reed, S. C., \& Evans, S. M. Alcohol Consumption as a Function of Dietary Restraint and The Menstrual Cycle in Moderate/Heavy ("at-risk") Female Drinkers. Eating Behaviors. 2012;13(3):285-8.

2. Faramarzi, M., Salmalian, H. Association of Psychologic and Nonpsychologic factors with primary dysmenorrhea. Iranian Red Crescent Medical Journal, 2014;16(8):e16307.

3. Nooh A., Abdul-Hady, \& Nadia El-Attar. Nature and Prevalence of Menstrual Disorders among Teenage Female Students at Zagazig University, Zagazig, Egypt. Journal of Pediatric and Adolescent Gynecology. 2016;29(2):137-142.

4. Hennegan J, Dolan C, Wu M, Scott L \& Montgomery P. Schoolgirls' Experience and Appraisal of Menstrual Absorbents in Rural Uganda: a Cross-Sectional Evaluation of Reusable Sanitary Pads. Reproductive Health. 2016;13(1):143.

5. Zhang Q., Wang Y. Y., Zhang Y., Zhang H. G., Yang Y., He Y., Xu J. H., Zhao J., Peng Z. Q., $\& \mathrm{Ma} X 1$. The Influence of Age at Menarche, Menstrual Cycle Length and Bleeding Duration on Time to Pregnancy: a large prospective cohort study among rural Chinese women. An International Journal of Obstretric and Gynae- cology. 2017;124(11):1654-1662.

6. Rigon F., De Sanctis V., Bernasconi S., Bianchin L., Bona G., Bozzola M., Buzi F., Radetti G., Tatò L., Tonini G., De Sanctis C., \& Perissinotto E. Menstrual Pattern and Menstrual Disorders among Adolescents: an Update Of The Italian Data. Italian Journal of Pediatrics. 2012;38,38.

7. Vo K. T., Grooms L., Klima J., Holland-Hall C., \& O'Brien S. H. Menstrual Bleeding Patterns and Prevalence of Bleeding Disorders In A Multidisciplinary Adolescent Haematology Clinic. Haemophilia. 2013;19(1):71-5.

8. Sharma S, Deuja S, \& Saha C. G. Menstrual Pattern among Adolescent Girls of Pokhara Valley: a cross sectional study. BMC Women's Health. 2016;16(1):74.

9. Ikhsan M., Siregar FGM., \& Muharam R. The Relationship Between Ramadan Fasting with Menstrual Cycle Pattern Changes in Teenagers. Middle East Fertility Society Journal. 2017;22(1):43-47.

10. Jones R. E., \& Lopez K. H. Human Reproductive Biology. London: Academic Press; 2014.

11. Dasharathy S. S., Mumford S. L., Pollack A. Z., Perkins N. J., Mattison D. R., WactawskiWende J., \& Schisterman EF. Menstrual Bleeding Patterns among Regularly Menstruating Women. American Journal of Epidemiology. 2012;175(6):536-45.

12. Depkes RI. Laporan Nasional Riset Kesehatan Dasar Tahun 2010. Jakarta: Depkes RI; 2010.

13. Badan Pusat Statistik Kabupaten Magelang [homepage on the Internet]. Kemiskinan dan pola konsumsi Kabupaten Magelang; 2016 [updated 2017 Des 27; cited 2018 Aug 17]. Available from: https://magelangkab.bps.go.id/publication/2017/12/27/ a $56 \mathrm{fcd} 5874713 \mathrm{f} 9 \mathrm{ed} 4 \mathrm{f} 06872 / \mathrm{kemi}-$ skinan-dan-pola-konsumsi-penduduk-kabupaten-magelang-2016.html.

14. Colrain I. M., \& Baker F. C. Changes in Sleep as a Function of Adolescent Development. Neuropsychology Review. 2011;21(1):5-21.

15. Lord C., Sekerovic Z., \& Carrier J. Sleep Regulation and Sex Hormones Exposure in Men and Women Across Adulthood. Pathologie Biologie. 2014;26(5):302-10.

16. Liu X., Chen H., Liu Z. Z., Fan F., \& Jia C. 
X. Early Menrche and Menstrual Problems are Associated with Sleep Disturbance in Large Sample of Chinese Adolescents Girl. Sleep. 2017;40(9).

17. Basch C. E., Basch C. H., Ruggles K.V., \& Rajan S. Prevalence of Sleep Duration on an Average School Night among 4 Nationally Representative Successive Samples of American High School Students, 2007-2013. Preventing Chronic Disease. 2014;11:E216.

18. Hysing M., Pallesen S., Stormark K. M., Lundervold A. J., \& Sivertsen B. Sleep Patterns And Insomnia among Adolescents: a population based study. Journal Sleep Research. 2013;22(5):549-556.

19. Meldrum R. C., \& Restivo E. The Behavioral and Health Consequences of Sleep Deprivation Among U.S.High School Students: relative deprivation matters. Preventive Medicine. 2014;63:24-28.

20. Gradisar M., Gardner G., \& Dohnt H. Recent Worldwide Sleep Patterns and Problems During Adolescence: A Review and Meta-Analysis Of Age, Region, and Sleep. Sleep Medicine. 2011;12(2):110-118.

21. Santos I. S., Minten G. C., Valle N. C., Tuerlinckx G. C., Silva A. B., \& Pereira G. A. Carriconde JF. Menstrual Bleeding Patterns: A Community-Based Cross-Sectional Study among Women Aged 18-45 Years in Southern Brazil. BMC Women's Health. 2011;11(1):26. DOI:10.1186/1472-6874-11-26.

22. Sarwono, Prawiroharjo. Ilmu Kebidanan. Yayasan Bina Pustaka Sarwono Prawirohardjo; Jakarta; 2014.

23. Wronka I., Teul I., \& Marchewka J. The Influence of Age at Menarche on The Prevalence of Disorders of The Menstrual Cycle among Healthy University Students. Annales Academiae Medicae Stetinensis. 2013;59(2):94-8

24. De La Vega R., Tomé-Pires C., Solé E., Racine M., Castarlenas E., Jensen M. P., \& Miró J. The Pittsburgh Sleep Quality Index: Validity and Factor Structure in Young People. Psychological Assessement. 2015;27(4): e22-7.

25. Curcio G., Tempesta D., Scarlata S., Marzano C., Moroni F., Rossini P. M, Ferrara M., De Gennaro L. Validity of the Italian Version of the Pittsburgh Sleep Quality Index (PSQI).
Neurological Sciences. 2013;34(4):511-9.

26. Alim I. Z. Uji Validitas daan Reliabilitas Instrumen Pittsburgh Sleep Quality Index versi Bahasa Indonesia [Tesis]. Jakarta: Fakultas Kedokteran Universitas Indonesia; 2015.

27. The American College of Obstetrician and Gynecologist. Menstruation in Girls and Adolescent: Using Menstrual Cycle as a Vital Sign. Obstetrics \& Gynecology. 2015;126(6): e143-146.

28. Dambhare D. G., Wagh S. V., \& Dudhe J. Y. Age at Menarche and Menstrual Cycle Pattern among School Adolescent Girls in Central India. Global Journal of Health Science. 2012; 4(1):105-111.

29. Zegeye D. T., Megabiaw B., \& Mulu A. Age at Menarche and The Menstrual Pattern of Secondary School Adolescents in Northwest Ethiopia. BMC Women's Health. 2009;9:29.

30. Heffner L. J., Schust D. J.. The Menstrual Cycle The Reproductive System At a Glance. UK: Wiley- Blackwell. 2010;38-9.

31. Peraturan Menteri Kesehatan Republik Indonesia [homepage on the internet]. Permenkes Indonesia no. 75 tahun 2013: Angka Kecukupan Gizi yang dianjurkan bagi Bangsa Indonesia; 2013 [cited 2017 Jul 3]. Available from: http://gizi.depkes.go.id/download/Kebijakan\%20Gizi/PMK\%2075-2013.pdf.

32. Patil S., Joglekar C., Desai M., Yadav A., Sonawane S., Chavan R., \& Mohite R. Nutritional Status and Psychological Impairment In Rural Adolescent Girls: Pilot data from "KOKAN" region of Western India. Frontiers in Public Health. 2018; 6: 160.

33. Wansink B., Payne C. R, \& Shimizu M. "Is this a meal or snack?" Situational Cues that Drive Perceptions. Appetite.2010;54:214-6.

34. Wadhera D., \& Capaldi E. D. Categorization of Foods as "snack" and "meal" by College Students. Appetite. 2012;58:882-8.

35. Larson N., Story M., Eisenberg M. E., \& Neumark-Sztainer D. Secular Trends in Meal and Snack Patterns among Adolescents From 1999 to 2010. Journal of the Academy of Nutrition and Dietetics. 2016;116(2):240-250.e2.

36. Mumford S. L., Chavarro J. E., Zhang C., Perkins N. J., Sjaarda L. A, Pollack A. Z., Schliep K. C., Michels K. A., Zarek S. M., Plowden T. 
C., Radin R. G., Messer L. C., Frankel R. A., \& Wactawski-Wende J. Dietary Fat Intake and Reproductive Hormone Concentrations and Ovulation in Regularly Menstruating Women. The American Journal of Clinical Nutrition. 2016;103(3):868-77.

37. Pérez P. A., Sánchez J. F., Maymo J. L., Dueñas J. L., Varone C. L., \& Ahanhez M. V. Role of Leptin in Female Reproduction; De Gruyter. Clinical Chemistry and Laboratory Medicine. 2015;53(1):15-28.

38. Vani K. R., Veena K. S., Subita L., Hemanth K. V. R., \& Bupathy A. Menstrual Abnormalities in School Going Girls are They Related to Dietary and Exercise Pattern? Journal of Clinical and Diagnostic Research. JCDR. 2013; 7(11):2537-2540.

39. Yavangi M., Amirzargar M. A., Amirzargar N., \& Dadashpour M. Does Ramadan Fasting has Any Effects on Menstrual Cycles?. Iranian Journal of Reproductive Medicine. 2013; 11(2):145-50.

40. Eittah H. F. A. Effect of Breakfast Skipping on Young Females' Menstruation. Health Science Journal. 2014;8(4):469-484.

41. Mohamadirizi S., \& Kordi M. The Relationship between Food Frequency and Menstrual Distress in High School Females. Iranian Journal of Nursing and Midwifery Research. 2015;20(6):689-93.

42. Dars S., Sayed K., \& Yousufzai Z. Relationship of Menstrual Irregularities to BMI and Nutritional Status in Adolescent Girls. Pakistan Journal of Medical Sciences. 2014;30(1): 141-144.

43. Hirshkowitz M., Whiton K., Albert S. M., Alessi C., Bruni O., DonCarlos L., Hazen N., Herman J., Katz E. S, Kheirandish-Gozal L., Neubauer D.N., O’Donnell A. E., Ohayon M., Peever J., Rawding R., Sachdeva R. C., Setters B., Vitiello M. V., Ware J. C, Adams Hillard P. J. National Sleep Foundation's Sleep Time Duration Recommendations: Methodology And Results Summary. Sleep Health. 2015;1(1):40-43.

44. Owens J. Insufficient Sleep in Adolescents and Young Adults: an Update on Causes and Consequences. Pediatrics. 2014;134(3):e92132.
45. Hysing M., Pallesen S., Stormark K. M., Jakobsen R., Lundervold A. J., Sivertsen B. Sleep and Use of Electronic Devices in Adolescence: Results from a Large Population Based Study. BMJ open, 2015;5(1):e006748.

46. Wheaton A. G., Chapman D. P., \& Croft J. B. School Start Times, Sleep, Behavioral, Health, and Academic Outcomes: A Review Of The Literature. The Journal of School Health. 2016;86(5):363-381.

47. Lim H. S., Kim T. H., Lee H. H., Park Y. H., Lee B. R., Park Y. J., \& Kim Y. S. Fast Food Consumption Alongside Socioeconomic Status, Stress, Exercise, and Sleep Duration are Associated with Menstrual Irregularities in Korean Adolescents: Korea National Health and Nutrition Examination Survey 20092013. Asia Pacific Journal of Clinical Nutrition. 2018;27(5):1146-1154.

48. Gomez-Gonzalez B., Dominguez-Salazar E., Hurtado-Alvarado G Esqueda-Leon E., Santana-Miranda R., Rojas-Zamorano J. A., \& Vel'azquez-Moctezuma J. Role of Sleep in the Regulation of the Immune System and the Pituitary Hormones. Annals of The New York Academy of Science. 2012;126:97-106.

49. Mehta N., Shafi F., \& Bhat A. Unique Aspects of Sleep in Women. Missouri Medicine. The Journal of Missiori State Medical Association. 2015;112(6):430-4.

50. Strauss J. F. Barbiieri R. Yen \& Jaffe's Reproductive Endocrinology: Physiology, Pathophysiology, and Clinical Management 7th edition.1600 John of Kennedy Blv: Philadelphia, PA 19103-2899; 2014.

51. Moen B. E., Baste V., Morken T., Alsaker K., Pallesen S., \& Bjorvatn B. Menstrual Characteristics and Night Work among Nurses. Industrial health. 2015;53(4):354-60.

52. Santos I. S., Minten G. C., Valle N. C., Tuerlinckx G. C., Silva A. B., Pereira G. A., Carriconde J. F. Menstrual Bleeding Patterns: a Community Based Cross Sectional Study among Women Aged 18-45 Years in Southern Brazil. BMC Women's Health. 2011;11(1):26.

53. Elshiekh M., Ali Mohammed A. M. Influence of Socioeconomic Status in the Age of Menarche And Duration of Menstrual Bleeding. Materia Socio-Medica. 2011;23(4):195-9. 